\title{
FEMALE ADVANTAGE? MANAGEMENT AND FINANCIAL PERFORMANCE IN MICROFINANCE
}

\author{
Sigurdur GUDJONSSON®1, Kari KRISTINSSON(1)2, \\ Haukur Freyr GYLFASON ${ }^{3}$, Inga MINELGAITE ${ }^{4}{ }^{*}$ \\ 1, 2, ${ }^{4}$ University of Iceland, School of Business, Iceland \\ ${ }^{3}$ Reykjavik University School of Business, Iceland
}

Received 15 October 2019; accepted 08 November 2019

\begin{abstract}
The purpose of the article is to investigate whether female presence in microfinance institutions' management team, i.e. board members, managers and loan officers, will improve their financial performance. We combine financial data on MFIs that is available from the MIX Market database with original data on the gender composition of MFIs' management team, who include board members, managers and loan officers. This original dataset of 223 MFIs is analyzed using Logit-Tobit regression models with return on assets (ROA) as the dependent variable and proportion of female board members, female loan officers and female managers as the main independent variables. We find that a higher proportion of female managers and female loan officers improve financial performance in microfinance, while a higher proportion of female board members does not. Our results indicate that a major contributor to the financial sustainability of microfinance institutions is having a higher rate of women in vital decision-making roles, especially lower level management positions.
\end{abstract}

Keywords: microfinance, gender, management, financial performance, firm.

JEL Classification: G21, L31, M14.

\section{Introduction}

Microfinance institutions (MFIs) are vehicles designed to help the poor who are stuck in a poverty cycle resulting from information asymmetry and lack of collateral for standard loans (Armendáriz and Morduch 2007). The purpose of MFIs is therefore to solve a market failure by providing the poor with loans otherwise not available to them, often called outreach. By providing these loans, MFIs are emphasizing the social aspect of banking. Their goal is not to maximize profit but rather to increase the availability of capital for those in need. However, microfinance institutions must also balance their financial performance in order to ensure their long-term survival.

Recent researches indicates that MFIs' management systems would improve with an increased female presence (Bassem 2009, Strom et al. 2014, Hartarska et al. 2014, Vishwakarma 2017, Ghosh and Guha 2019). This is an important issue since the MFIs are female-oriented on the customer side, in fact about 70 percent of all microfinance borrowers are women (Armendáriz and Morduch 2007, Reed 2011). Despite the fact that researches on female management and MFI performances are still relatively rare, some notable literature has been created over the last few years. Bassem (2009) found that having female board members improves outreach, and both Strom et al. (2014) and Hartarska et al. (2014) found that having a female CEO tends to improve MFIs' financial performance. Furthermore, Vishwakarma (2017) found the same was true for female board members. The literature also indicates that lower level management might have an important, but often overlooked, role to play in the performance of MFIs. Agier and Szafarz (2013) found female loan officers to provide lower loans to females. Likewise, Beck et al. (2013) and Tchakoute-Tchuigoua and Soumaré (2019) discovered that in traditional banking having female loan officers is related to superior financial performance rather than having male loan officers.

In this paper, we will build on matching theory (Becker 1973) and a unique dataset of 223 MFIs to extend the prior literature by investigating how a female presence in management teams (board members, managers and loan officers) in MFIs is linked to financial performance. Matching theory was first introduced to the microfinance

*Corresponding author. E-mail: inga.minelgaite@gmail.com 
literature by Ghatak (2000), who showed that female borrowers were more likely to group themselves with less risky borrowers who tended to be women. Female MFIs borrowers therefore "matched" horizontally (Ghatak 2000). This theoretical argument was further built on by Strom et al. (2014), who that found that microfinance institutions with female CEOs showed better financial performance. Building on this literature, we investigate whether the financial performance of MFIs increases with the presence of female managers, female loan officers and female board members.

Our paper contributes to two flourishing strands of literature. Firstly, it adds novel results to the microfinance literature by looking at the gender composition for each level of the MFI management team (board members, managers and loan officers). Our results add to the current knowledge on the financial performance of MFIs (Strom et al. 2014, Leite at al. 2018). Secondly, it contributes to studies in management that have analyzed the importance of management gender in contexts other than microfinance (Adams and Ferreira 2009, Krishnan and Park 2005, García-Meca et al. 2015, Brieger et al. 2017, Moreno-Gómez et al. 2018). Our results show that female managers and female loan officers improve MFIs' financial performance, but the presence of female board members does not have an effect.

The paper is structured as follows. First, the literature on female management and their influence on firm performance is discussed. Within this discussion our hypotheses are stated. This is followed by presenting the estimation method, model and the data. Finally, the empirical results are outlined before the paper concludes.

\section{Financial performance and women in microfinance}

The microfinance industry has received considerable attention in recent years. Relatively unknown in the late 1970s, the microfinance business has since developed quickly, serving an ever-increasing proportion of those from a poor social and economic background (Maes and Reed 2012). In contrast to most other organizations, MFIs have two key objectives: a social one called outreach, as well as a financial one called sustainability. The dual performance goals of outreach and sustainability mean that MFIs are able to provide the poor with capital (outreach) while still being able to survive in the long term (sustainability).

The MFIs are designed to solve a market failure between normal banks and borrowers (Armendáriz and Morduch 2007). Frequently the credit requested by potential microfinance borrowers is too low for the MFIs to earn back the original investment, and additionally the MFIs do not have adequate data about their borrowers to evaluate reimbursement rates. Furthermore, borrowers often do not have any collateral, which adds further to the risk (Armendáriz and Morduch 2007). However, MFIs are normally mindful of these constraints and position themselves towards the poor in the long tail of Pareto's 80/20 principle (Serrano-Cinca and Suitérrez-Nieto 2014). As women are typically relatively poorer than men, they comprise the majority of MFI borrowers. This is especially true in rural areas where cultural norms make it harder for women to borrow money (Duflo 2012, D'Espallier and Vanroose 2017). In fact, 70 percent of all MFIs' borrowers are women (Reed 2011). For this reason, gender issues have become a relevant topic of interest for many MFI researchers.

An interesting aspect of MFI loan practices is that microfinance borrowers are often grouped together and held to be collectively responsible for repayments. Ghatak (2000) investigated how microfinance borrowers "matched" with each other in groups and found that people with similar traits grouped together. Women were much more likely to group with each other because they tended to be more risk-averse than their male counterparts. In other words, their risk-aversion and gender were the shared traits and they therefore "matched" each other. Ghatak's theoretical argument was based on Becker's (1973) theory of marriage matching. Originally this theory was aimed at explaining the reasons why people chose their marriage partners. Becker (1973) found people to "match" with partners who had similar traits. These traits could be the person's IQ, ethnic background, physical features, and other various forms of basic similarities.

Following Ghatak (2000), Mersland and Strom (2009) also applied Becker's (1973) marriage matching theory to data on MFIs. Mersland and Strom (2009) found that having female CEOs led to better financial performance. Their result was later supported by Strom et al. (2014) who also found that female CEOs increased MFIs' financial performance. Additionally, the increase in financial performance could also be seen if the chairman of the board was a woman (Strom et al. 2014, Vishwakarma 2017, Gosh and Guha 2019; Tchakoute-Tchuigoua and Soumaré, 2019). However, Kittilaksanawong and Zhao (2018) found that MFIs with a higher level of lending to women had reduced financial sustainability.

Research streams outside of the MFI literature have also been interested in gender differences in financial decisions. Within financial economics, researchers on investment decisions, corporate financial decisions and mutual fund management have investigated gender differences. In general, studies find that women seem to be more risk averse than men (e.g. Barsky et al. 1997, Sunden and Surette 1998, Agnew et al. 2003, Charness and Gneezy 2007), which might lead female managers to make better decisions in high risk areas such as microfinance. Other studies have found that men are more overconfident than women (e.g. Barber and Odean 2001, Niederle and Vesterlund 2007). The evidence for performance differences between the genders has, however, been mixed. Barber and Odean (2001) find that female investors perform better. Huang and Kisgen (2009) also find that female CEOs 
perform better in acquisitions and García-Meca et al. (2015) found women on boards to increase performance.

Outside financial economics researchers have also found a more indirect influence of women in management. Billimoria (2000) found that a female presence in organizations sent a signal to younger women in the organization and further encouraged them to perform well. Appold et al. (1998) found that the presence of women improved the work environment and eventually performance. Eagly et al. (2003) confirmed this finding, and found that women in senior managerial positions were better at helping and mentoring their subordinates to help them reach their full potential, which positively affected the firm's performance. Furthermore, empirical results have shown female managers tend to improve the organizational performance (e.g. Adams and Ferreira 2009, Krishnan and Park 2005, Cordeiro and Stites-Doe 1997, Catalyst 2004). Both experimental and real-world data also suggests that women tend to be more risk-averse and less self-confident than men, especially in financial decision-making and investments (Powell and Ansic 1997, Byrnes et al. 1999, Barber and Odean 2001, Eckel and Grossman 2008, Croson and Gneezy 2009).

As the empirical literature indicates that the presence of women in management positions could influence the performance of MFIs, we put forth the following hypothesis:

H1: There is a positive association between the proportion of female managers and the MFI's financial performance.

Decision making is, however, not only in the hands of upper management. In microfinance institutions, loan officers are in close contact with borrowers and are a key decision maker when it comes to loan procedures and treatment. Important decision making can thus be taking place below the top level of the organization (Fama and Jensen 1983). Prior literature has also found that women in lower-level management positions have an important role in the financial performance of their firms (Dwyer et al. 2003). Women in senior positions focus more on developing and mentoring their subordinates, urging them to achieve their maximum capacity (Eagly et al. 2003). Females in management positions therefore inspire lower level employees. This is in accordance with the transformational leadership style whereby leaders spot potential in their followers and nurture it (Burns 1978). Furthermore, the female leadership style is often more focused on collective problem-solving and decision making (Jogulu and Wood 2006, Mandell and Pherwani 2003).

One of the most important functions in a finance institution is the loan officer. There are several reasons to expect women loan officers to perform differently than their male counterparts. Studies have shown differences in preferences between women and men (Croson and Gneezy 2009). For example, women tend to be more risk averse than men (e.g. Barsky et al. 1997, Sunden and Surette
1998, Agnew et al. 2003, Charness and Gneezy 2007) and men tend to be more overconfident than women (e.g. Barber and Odean 2001, Niederle and Vesterlund 2007). It is therefore possible that female loan officers grant loans more restrictively and screen potential customers better due to them having higher risk aversion and being less confident. Beck et al. (2013) found that female loan officers perform better when dealing with female borrowers. This is supported by Bellucci et al. (2010) who find that female loan officers are more likely to restrict credit availability to new unestablished borrowers than their male counterparts. We therefore state the second hypothesis as follows:

$\mathrm{H} 2$ : There is a positive association between the proportion of female loan officers and the MFI's financial performance.

Board members have two main goals according to Finkelstein and Hambrick (1996). Firstly, they are to influence the strategic decision-making within the organization. Secondly, they are to serve as supervisors since they represent the company's owners. By implementing these two goals, board members can affect organizational performance (Finkelstein et al. 1996). Since board members affect organizational performance, organizations should strive to find suitable candidates for the job. Brammer et al. (2007) found that an organization should acknowledge that board members are not evenly distributed among different demographic groups. Therefore, excluding females from the board would systematically deny the organization access to qualities and experiences that are inherent in women. Indeed, women's special qualities manifest in a different managerial style than their male counterparts (Eagly and Johnson 1990). Women may be more willing to discuss alarming issues than males and generally they enrich discussions at board meetings (Bilimoria and Huse 1997). Women also tend to have better meeting attendance records than men (Adams and Ferreira 2009).

However, the empirical research on female presence on boards and their effects on financial performance is inconsistent. Several scholars have found gender diversity to have a positive effect on financial performance (e.g. Rosenstein and Wyatt 1990, Singh et al. 2001, Carter et al. 2003, Erhardt et al. 2003, Catalyst 2004, Campbell and Minguez-Vera 2008, Bart and McQueen 2013, GarcíaMeca et al. 2015). Others have found that gender diversity had a negative effect (e.g. Adams and Ferreira 2009, Smith et al. 2006), while another group of scholars found no relationship whatsoever (e.g. Shrader et al. 1997, Dwyer et al. 2003, Miller and Triana 2009).

A possible explanation for these results may lie in industry differences. The presence of women on boards and their effect on financial performance may therefore depend on the industry characteristics (Harrigan 1981, Brammer et al. 2007). In fact, Brammer et al. (2007) determined that women were often present on boards of firms that had close proximity to their final consumers, such 
as the media, retailing and notably banking. The microfinance industry, being a mixture of developing institutions and banks, is also very female specific (Reed 2011). Furthermore, since women board members may bring valuable knowledge of the female market (Daily et al. 1999), we put forth the following hypothesis.

$\mathrm{H} 3$ : There is a positive association between the proportion of female board members and the MFI's financial performance.

\section{Data and empirical model}

For the data sources and sample selection, the data used in this study were from the MIX market (MixMarket. org) which is the most used data source for MFI research. This data was then matched with original, hand-collected data. The hand-collected data were mostly obtained from financial statements, rating reports and the MFIs' own homepages. When insufficient information was supplied from these sources, the missing information had to be collected from external sources, such as from the webpage "LinkedIn", where information on the MFIs' CEOs and other staff was sometimes provided. The dataset consists of 223 MFIs.

The Dependent variable Financial performance was measured by the Return on Asset (ROA). This particular variable was available from the MixMarket dataset and could be downloaded from mixmarket.org. It is a commonly used proxy to measure MFIs' financial performance and while it is usually used in financial literature aiming for maximization of profit, in the microfinance literature it is used as a proxy for sustainability. The financial performance goal of MFIs is sustainability rather than profit maximization.

The main independent explanatory variables of interest are the gender specific variables. For the gender specific variables, female board members were measured as the proportion of female board members, female loan officers were the proportion of female loan officers, and female managers were the proportion of managers who are women. All of these variables were sourced from the MixMarket dataset.

In all the models, we controlled for the following variables: MFI specific variables where: MFI size measured by the logarithm of total assets, MFI age measured in years since commencement, and MFI type measured as a dummy variable (NGO vs Non-bank Financial Institution). We controlled for lending methodology since studies show that the type of lending methodology used influences the success of these organizations. We, therefore, included the dummy variable Individual which takes the value of one if the MFI uses individual lending technology. The information on lending methodology were hand-collected from the MFIs' own webpages, financial statements or independent rating reports. Very few MFIs in this research only used the group lending method.

Variables included as management specific variables were: Fixed-wage, a dummy for wages, which is not based on performance and experience. The variable that is a proxy for managers' quality (Experience) was measured as years of work experience. Both these variables had to be hand-collected from the MFIs' own webpages or from their rating reports. In some cases, "LinkedIn" became helpful to see managers' information about their work experience.

Variables included as board specific variables were: Board size, measured as number of board members (this variable is available from the MixMarket platform), and Independent, measured as the proportion of non-affiliated board members. This variable had to be hand-collected. The variables included in the external governance mechanism were: Regulation, a dummy with a value of one if the MFI was supervised by the central bank or other bank supervisory agency; and Rated, dummy with a value of one if the MFI was subject to independent evaluation or rating by an external organization.

The country specific macroeconomic control variable was: Size of the economy, which was the logarithm of the country's GDP and taken from The World Bank Development Indicators.

To test the three hypotheses, this study uses five econometric models. Model 1 is the base model where only the control variables are included. Models 2, 3 and 4 include the explanatory and control variables, and Model 5 includes all explanatory and control variables (see Table 3).

\section{Regression results}

As can be seen in Table 1, around a third of all managers, loan officers, and board members of this study were female. Additionally, the MFIs average financial performance was 0.02 , implying a $2 \%$ average return on assets.

The correlation between performance and the proportion of female loan officers and female board members

Table 1. Summary statistics

\begin{tabular}{|l|c|c|c|c|c|}
\hline & $\mathrm{N}$ & Mean & $\begin{array}{c}\text { Std. De- } \\
\text { viation }\end{array}$ & $\begin{array}{c}\text { Mini- } \\
\text { mum }\end{array}$ & $\begin{array}{c}\text { Maxi- } \\
\text { mum }\end{array}$ \\
\hline Female managers & 218 & 0.33 & 0.31 & 0 & 1 \\
\hline Female loan officers & 213 & 0.35 & 0.28 & 0 & 1 \\
\hline $\begin{array}{l}\text { Female board } \\
\text { members }\end{array}$ & 222 & 0.31 & 0.25 & 0 & 1 \\
\hline $\begin{array}{l}\text { Financial } \\
\text { performance }\end{array}$ & 223 & 0.02 & 0.09 & -0.51 & 0.31 \\
\hline MFIs Size & 223 & 16.17 & 1.59 & 12.25 & 20.49 \\
\hline Mfis age & 223 & 15.32 & 7.98 & 3 & 60 \\
\hline MFIs type & 223 & 0.55 & 0.5 & 0 & 1 \\
\hline Individual & 213 & 0.93 & 0.26 & 0 & 1 \\
\hline Fixed-wage & 215 & 0.75 & 0.43 & 0 & 1 \\
\hline Experience & 205 & 14.63 & 7.24 & 3 & 35 \\
\hline Board size & 223 & 6.39 & 3.15 & 1 & 27 \\
\hline
\end{tabular}


End of Table 1

\begin{tabular}{|l|c|c|c|c|c|}
\hline & $\mathrm{N}$ & Mean & $\begin{array}{c}\text { Std. De- } \\
\text { viation }\end{array}$ & $\begin{array}{c}\text { Mini- } \\
\text { mum }\end{array}$ & $\begin{array}{c}\text { Maxi- } \\
\text { mum }\end{array}$ \\
\hline Independent & 169 & 0.51 & 0.35 & 0 & 1 \\
\hline Regulation & 222 & 0.5 & 0.5 & 0 & 1 \\
\hline Rated & 222 & 0.59 & 0.49 & 0 & 1 \\
\hline Size of the economy & 219 & 10.91 & 0.84 & 9.58 & 12.92 \\
\hline $\begin{array}{l}\text { Effective numbers of } \\
\text { observ. }\end{array}$ & 157 & & & & \\
\hline
\end{tabular}

was positive and significant at the $10 \%$ significance level (see Table 2). The correlations between performance (Table 2) and the proportion of female managers was, however, non-significant. The regression results are shown in Table 3. The independent variables were entered simultaneously having ascertained that the assumption of multicollinearity was not violated (all tolerance scores were higher than 0.4 and VIF scores were below 2.2).

Model 1 represents the base model where only the control variables are included (see Table 3). As shown in

Table 2. Correlations between variables

\begin{tabular}{|c|c|c|c|c|c|c|c|c|c|c|c|c|c|c|c|}
\hline $\begin{array}{c}\text { Variab- } \\
\text { les }\end{array}$ & 1 & 2 & 3 & 4 & 5 & 6 & 7 & 8 & 9 & 10 & 11 & 12 & 13 & 14 & 15 \\
\hline $\begin{array}{l}\text { 1. Fe- } \\
\text { male } \\
\text { mana- } \\
\text { gers }\end{array}$ & 1 & & & & & & & & & & & & & & \\
\hline $\begin{array}{l}\text { 2. Fe- } \\
\text { male } \\
\text { loan } \\
\text { officers }\end{array}$ & $0.407^{\star * *}$ & 1 & & & & & & & & & & & & & \\
\hline $\begin{array}{l}\text { 3. Fe- } \\
\text { male } \\
\text { board } \\
\text { mem- } \\
\text { bers }\end{array}$ & $0.271^{\star * *}$ & $0.188^{\star * *}$ & 1 & & & & & & & & & & & & \\
\hline $\begin{array}{l}\text { 4. Fi- } \\
\text { nancial } \\
\text { perfor- } \\
\text { mance }\end{array}$ & $0.141^{\star *}$ & $0.196^{\star * *}$ & $0.138^{\star *}$ & 1 & & & & & & & & & & & \\
\hline $\begin{array}{l}\text { 5. MFIs } \\
\text { size }\end{array}$ & -0.079 & -0.089 & $-0.127^{\star}$ & 0.057 & 1 & & & & & & & & & & \\
\hline $\begin{array}{l}\text { 6. MFIs } \\
\text { age }\end{array}$ & -0.062 & 0.124 & 0.091 & 0.098 & $0.17^{\star *}$ & 1 & & & & & & & & & \\
\hline $\begin{array}{l}\text { 7. MFIs } \\
\text { type }\end{array}$ & -0.009 & 0.069 & 0.11 & 0.05 & $-0.239^{* * *}$ & $0.267^{\star * *}$ & 1 & & & & & & & & \\
\hline $\begin{array}{l}\text { 8. Indi- } \\
\text { vidual }\end{array}$ & 0.038 & -0.055 & 0.041 & 0.086 & -0.004 & 0.067 & -0.07 & 1 & & & & & & & \\
\hline $\begin{array}{l}\text { 9. Fi- } \\
\text { xed- } \\
\text { wage }\end{array}$ & -0.011 & 0.093 & 0.04 & 0.061 & $-0.269^{\star * *}$ & $0.143^{*}$ & $0.402^{\star * *}$ & 0.008 & 1 & & & & & & \\
\hline $\begin{array}{l}10 . \\
\text { Expe- } \\
\text { rience }\end{array}$ & $-0.129^{*}$ & -0.108 & -0.022 & -0.055 & $0.167^{\star *}$ & $0.132^{*}$ & $0.146^{\star *}$ & -0.037 & -0.046 & 1 & & & & & \\
\hline $\begin{array}{l}11 . \\
\text { Board } \\
\text { size }\end{array}$ & -0.088 & -0.031 & -0.008 & -0.021 & $0.34^{* * *}$ & $0.216^{* * *}$ & 0.077 & -0.002 & -0.094 & 0.274 & 1 & & & & \\
\hline $\begin{array}{l}12 \text { In- } \\
\text { depen- } \\
\text { dent }\end{array}$ & 0.021 & 0.039 & -0.075 & -0.085 & $-0.136^{*}$ & $-0.166^{* *}$ & 0.044 & 0.006 & 0.005 & -0.017 & -0.102 & 1 & & & \\
\hline $\begin{array}{l}13 . \\
\text { Regu- } \\
\text { lation }\end{array}$ & -0.058 & -0.102 & -0.073 & $-0.12^{\star}$ & $0.23^{* * *}$ & $-0.226^{\star * *}$ & -0.479 & -0.021 & $-0.355^{\star * *}$ & 0.092 & 0.059 & -0.043 & 1 & & \\
\hline $\begin{array}{l}14 . \\
\text { Rated }\end{array}$ & -0.064 & -0.057 & 0.008 & $0.15^{\star *}$ & $0.398^{\star * *}$ & 0.037 & $-0.176^{\star * *}$ & 0.046 & $-0.222^{\star * *}$ & -0.037 & -0.006 & 0.025 & 0.105 & 1 & \\
\hline $\begin{array}{l}\text { 15. Size } \\
\text { of the } \\
\text { eco- } \\
\text { nomy }\end{array}$ & $-0.12^{\star}$ & 0.009 & -0.067 & 0.011 & 0.103 & -0.07 & 0.048 & $-0.266^{* * *}$ & -0.112 & $0.152^{\star *}$ & 0.088 & -0.102 & -0.043 & 0.086 & 1 \\
\hline
\end{tabular}

Notes: ${ }^{\star * \star} p<.01$ (two tailed); ${ }^{* *} p<.05$ (two tailed); ${ }^{\star} p<.10$ (two tailed). 
Table 3, we find support for Hypotheses 1 (Model 2) and 2 (Model 3), but not Hypothesis 3 (Model 4). MFIs with a higher proportion of female managers had better financial performance (ROA), all else being equal. Similarly, MFIs with a higher proportion of female loan officers had better financial performance. These results are in line with the findings of Adams and Ferreira (2009) and Krishnan and Park (2005) which showed that female managers have a positive effect on firms' financial performance (Table 3 ). The results also confirm and further expand on the findings of Beck et al. (2013) and Mengoli et al. 2017 on the impact of experienced female loan officers on a firm's performance.

Table 3. Regression models

\begin{tabular}{|c|c|c|c|c|c|}
\hline Variables & Model 1 & Model 2 & Model 3 & Model 4 & Model 5 \\
\hline $\begin{array}{l}\text { (cons- } \\
\operatorname{tant})\end{array}$ & 0.003 & -0.035 & 0.025 & 0.022 & -0.021 \\
\hline $\begin{array}{l}\text { MFIs } \\
\text { size }\end{array}$ & 0.003 & 0.004 & 0.001 & 0.004 & -0.008 \\
\hline MFIs age & 0 & 0 & -0.001 & 0 & 0 \\
\hline $\begin{array}{l}\text { MFIs } \\
\text { type }\end{array}$ & 0.016 & 0.013 & 0.013 & 0.014 & 0.013 \\
\hline $\begin{array}{l}\text { Indi- } \\
\text { vidual }\end{array}$ & 0.021 & 0.018 & 0.028 & 0.019 & 0.031 \\
\hline $\begin{array}{l}\text { Fixed- } \\
\text { wage }\end{array}$ & 0.007 & 0.008 & 0.006 & 0.007 & 0.003 \\
\hline $\begin{array}{l}\text { Expe- } \\
\text { rience }\end{array}$ & 0 & 0 & 0 & 0 & -0.001 \\
\hline $\begin{array}{l}\text { Board } \\
\text { size }\end{array}$ & 0 & 0 & 0.001 & -0.001 & 0.001 \\
\hline $\begin{array}{l}\text { Inde- } \\
\text { pendent }\end{array}$ & -0.029 & -0.029 & -0.026 & -0.028 & -0.02 \\
\hline $\begin{array}{l}\text { Regu- } \\
\text { lation }\end{array}$ & -0.023 & -0.023 & -0.019 & -0.023 & -0.011 \\
\hline Rated & $0.043^{\star *}$ & $0.046^{\star * *}$ & $0.0042^{* *}$ & $0.042^{\star *}$ & 0.024 \\
\hline $\begin{array}{l}\text { Size } \\
\text { of the } \\
\text { economy }\end{array}$ & -0.005 & -0.005 & -0.007 & -0.004 & 0.014 \\
\hline $\begin{array}{l}\text { Female } \\
\text { manager }\end{array}$ & & $0.044^{\star *}$ & & & 0.021 \\
\hline $\begin{array}{l}\text { Female } \\
\text { loan } \\
\text { officers }\end{array}$ & & & $0.082^{* * *}$ & & $0.082^{* * *}$ \\
\hline $\begin{array}{l}\text { Female } \\
\text { board } \\
\text { members }\end{array}$ & & & & 0.029 & -0.026 \\
\hline $\mathrm{R} 2$ & 0.093 & 0.116 & 0.130 & 0.098 & 0.229 \\
\hline $\begin{array}{l}\text { Adjusted } \\
\text { R2 }\end{array}$ & 0.027 & 0.045 & 0.058 & 0.027 & 0.142 \\
\hline
\end{tabular}

Notes: ${ }^{\star * \star *} p<0.001 ;{ }^{\star * \star} p<0.001 ;{ }^{\star *} p<0.05 ;{ }^{\star} p<0.10$.

We did not find support for hypothesis 3, which is in sharp contrast to the results of Rosenstein and Wyatt (1990), Singh et al. (2001), García-Meca et al. (2015) and Vishwakarma (2017) on the positive effects of gender diversity in the boardroom on firms' financial performance, but they do align with the findings of Bassem (2009) and Hartarska (2005).

When including all the explanatory variables in the same model (Model 5), the picture becomes more complicated. The variables for proportion of female managers and loan officers, nonetheless, retained their positive association with financial performance, although the proportion of female managers was no longer statistically significant.

\section{Discussion}

Like all empirical research, this study has several limitations that stimulate ideas for further research. To start with, our research is limited to microfinance, a specific industry with unique characteristics that might not be present in other industries. Extending our results to another setting would help tease out whether our results can be generalized. Secondly, this study is limited to the number of microfinance firms that provided information on the gender composition of their management team. A larger dataset would help with regards to the different types of MFIs, e.g. would we find different outcomes with NGOs than Cooperatives and Credit Unions? Thirdly, the inclusion of extra constructs in the research model - e.g. cultural variables and human resource management - would provide a more comprehensive test of the relationships predicted using more advanced statistical analysis.

It would thus be interesting for future research to investigate why women appear to improve the financial performance of MFIs. Since research seems to show that females have a different leadership style compared to males, characterized by cooperation and collaboration (Jogulu and Wood 2006, Mandell and Pherwani 2003), this could be a valuable avenue to investigate.

Our research relates to important gender issues such as women empowerment and poverty issues. Women in charge of MFIs means that not only is financial performance of these institutions improving, but female empowerment increases simultaneously since women become in control of the institutions. Further more, since presence of women loan officers leads to that women have better change to receive loans, the unbanked poor women are more likely to improve their lives and move away from being trapped into poverty.

\section{Conclusions}

Previous studies linking gender diversity in MFIs to their financial performance have predominantly focused on the board level (Bassem 2009). However, the diversity in the composition of the board might be a poor proxy for the effects of gender diversity on financial performance, since key decision makers are at various levels in the organization. Therefore, it is necessary to look at a broader set of decision makers and analyze how gender diversity at all 
levels of an organization affects financial performance.

The current research contributes to the microfinance literature in two ways. Firstly, by investigating the impact of lower levels of key decision makers in MFIs, we find that female managers improve financial performance. We also find this to be true for female loan officers. Our findings therefore suggest that the female influence on financial performance might be concentrated away from the upper echelons of the MFIs' management team. This is in line with the outcomes of other literature, which has found that gender diversity in lower-level management is an important aspect to consider (Dwyer et al. 2003, Ghosh and Guha 2019), as well as research which has found that female supervisors improve the financial performance of organizations (Adams and Ferreira 2009, Krishnan and Park 2005, Cordeiro and Stites-Doe 1997, Catalyst 2004). Important decision making can thus be of influence below the top level of the organization (Fama and Jensen 1983). Prior literature has also found that women in lower-level management positions have an important role in the financial performance of their firms. Secondly, our research confirms previous findings which showed that female board members do not improve the financial performance of MFIs (Hartarska 2005). Although research into industries other than microfinance has found that female board members improve financial performance (Opstrup and Villadsen 2015, Vishwakarma 2017), this effect can possibly be attributed to industry-specific variables that are not present in microfinance. In conclusion, the results of this study suggest that gender diversity is positively related with the financial performance of MFIs, but this effect seems to be limited to the lower levels of the management team. This result may help to explain why previous studies into gender diversity in microfinance have not found a positive relationship with financial performance. However, further research is needed for a more thorough understanding of how gender diversity contributes to financial performance. We hope that this research will spur further studies on gender diversity and financial performance in MFIs.

\section{References}

Adams R, Ferreira D (2009) Women in the boardroom and their impact on governance and performance. Journal of Financial Economics 94 (2): 2910-309.

https://doi.org/10.1016/j.jfineco.2008.10.007

Agier I, Szafarz A (2013) Microfinance and gender: Is there a glass ceiling on loan size? World Development 42: 165-181. https://doi.org/10.2139/ssrn.1573872

Agnew J, Balduzzi P, Sundén A (2003) Portfolio choice and trading in a large 401(k) plan. American Economic Review 93 (1): 193-215. https://doi.org/10.1257/000282803321455223

Appold SJ, Siengthai S, Kasarda JD (1998) The employment of women managers and professionals in an emerging economy: Gender inequalities as an organizational practice. Administrative Science Quarterly 43 (3): 538-565. https://doi.org/10.2307/2393675

Armendáriz B, Morduch J (2007) The economics of microfinance (2nd ed.). The MIT Press: Cambridge. Massachusetts. USA.
Barber BM, Odean T (2001) Boys will be boys: gender, overconfidence, and common stock investment. Quarterly Journal of Economics 116 (1): 261-292.

https://doi.org/10.1162/003355301556400

Barsky RB, Juster FT, Kimball MS, Shapiro MD (1997) Preference parameters and behavioral heterogeneity: an experimental approach in the health and retirement study. Quarterly Journal of Economics 112 (2): 537-579 http://hdl.handle.net/10.1162/003355397555280

Bart C, McQueen G (2013) Why women make better directors. International Journal of Business Governance and Ethics 8 (1): 93-99. https://doi.org/10.1504/IJBGE.2013.052743

Bassem BS (2009) Governance and performance of microfinance institutions in Mediterranean countries. Journal of Business Economics and Management 10 (1): 31-43. https://doi.org/10.3846/1611-1699.2009.10.31-43

Beck T, Behr P, Guettler A (2013) Gender and banking: Are women better loan officers? Review of Finance 17 (4): 12791321. https://doi.org/10.1093/rof/rfs028

Becker GS (1973) A theory of marriage: Part I. Journal of Political Economy 81 (4): 813-846. https://doi.org/10.1086/260084

Bilimoria D (2000) Building the business case for women corporate directors. In: Burke RJ, Mattis MC (eds) Women on corporate boards of directors. Issues in Business Ethics 14. Springer, Dordrecht. https://doi.org/10.1007/978-90-481-3401-4_3

Bilimoria D, Huse M (1997) A qualitative comparison of the boardroom experiences of US and Norwegian women corporate directors. International Review of Women and Leadership 3 (2): 63-73.

Brammer S, Millington A, Pavelin S (2007) Gender and ethnic diversity among UK corporate boards. Corporate Governance: An International Review 15 (2): 393-403. https://doi.org/10.1111/j.1467-8683.2007.00569.x

Brieger SA, Francoeur C, Welzel C, Ben-Amar W (2017) Empowering women: the role of emancipative forces in board gender diversity. Journal of Business Ethics 155 (2): 495-511. https://doi.org/10.1007/s10551-017-3489-3

Burns JM (1978) Leadership. Harper Torchbooks, New York, NY. Byrnes J, Miller P, David C, William D (1999) Gender differences in risk taking: A meta-analysis. Psychological Bulletin 125 (3): 367-383. https://doi.org/10.1037/0033-2909.125.3.367

Campbell K, Mínguez-Vera A (2008) Gender diversity in the boardroom and firm financial performance. Journal of Business Ethics 83 (3): 435-451. https://doi.org/10.1007/s10551-007-9630-y

Carter DA, Simkins BJ, Simpson WG (2003) Corporate governance, board diversity, and firm value. The Financial Review 38 (1): 33-53. https://doi.org/10.1111/1540-6288.00034

Catalyst (2004) The bottom line: Connecting corporate performance and gender diversity. New York, NY: Catalyst.

Charness G, Gneezy U (2007) Strong evidence for gender differences in investment. Working Paper. https://doi.org/10.2139/ssrn.648735

Cordeiro JJ, Stites-Doe S (1997) The impact of women managers on firm performance: Evidence from large U.S. firm. International Review of Women and Leadership 3 (1): 1-20.

Corson R, Gneezy U (2009) Gender differences in preferences. Journal of Economic Literature 47 (2): 448-474. https://doi.org/10.1257/jel.47.2.448

Daily CM, Certo ST, Dalton DR (1999) A decade of corporate women: Some progress in the boardroom, none in the executive suite. Strategic Management Journal 20 (1): 93-99. https://doi.org/10.1002/(SICI)1097-0266(199901)20:1<93:: AID-SMJ18>3.0.CO;2-7 
Dwyer S, Richard OC, Chadwick K (2003) Gender diversity in management and firm performance: The influence of growth orientation and organizational culture. Journal of Business Research 56 (12): 1009-1019.

https://doi.org/10.1016/S0148-2963(01)00329-0

Duflo E (2012) Women empowerment and economic development. Journal of Economic Literature 50 (4): 1051-1079. https://doi.org/10.1257/jel.50.4.1051

Eagly AH, Johannesen-Schmidt MC, van Engen ML (2003) Transformational, transactional, and laissez-faire leadership styles. A meta-analysis comparing women and men. Psychological Bulletin 129 (4): 569-591.

https://doi.org/10.1037/0033-2909.129.4.569

Eagly AH, Johnson B (1990) Gender and leadership style: A meta-analysis. Psychological Bulletin 108 (2): 233-256. https://doi.org/10.1037/0033-2909.108.2.233

Eckel CC, Grossman PJ (2008) Men women and risk aversion: experimental evidence. Handbook of Experimental Economics Results 1: 1061-1073. https://doi.org/10.1016/S1574-0722(07)00113-8

Erhardt NL, Werbel JD, Shrader CB (2003) Board of director diversity and firm financial performance. Corporate Governance 11 (2): 102-111. https://doi.org/10.1111/1467-8683.00011

Fama EF, Jensen MC (1983) Separation of ownership and control. Journal of Law and Economics 26 (2): 301-325. https://doi.org/10.1086/467037

Finkelstein S, Hambrick D (1996) Strategic leadership: top executives and their effects on organizations. St. Paul. MN: West.

García-Meca E, García-Sánchez IM, Martínez-Ferrero J (2015) Board diversity and its effects on bank performance: An international analysis. Journal of Banking and Finance 53: 202-214. https://doi.org/10.1016/j.jbankfin.2014.12.002

Ghatak M (2000) Screening by the company you keep: Joint liability lending and the peer selection effect. The Economic Journal 110 (465): 601-631.

https://doi.org/10.1111/1468-0297.00556

Ghosh C, Guha S (2019) Role of gender on the performance of Indian microfinance institutions. Gender in Management: An International Journal: 1754-2413.

https://doi.org/10.1108/GM-03-2019-0036

Harrigan KR (1981) Number and positions of women elected to corporate boards. Academy of Management Journal 24 (3): 619-625. https://doi.org/10.5465/255580

Hartarska V, Nadolnyak D, Mersland R (2014) Are women better bankers to the poor? Evidence from rural microfinance institutions. American Journal of Agricultural Economics 96 (5): 1291-1306. https://doi.org/10.1093/ajae/aau061

Hartaska V (2005) Governance and performance of microfinance institutions in central and Eastern Europe and the newly independent states. World Development 33 (10): 627-1643. https://doi.org/10.1016/j.worlddev.2005.06.001

Huang J, Kisgen D (2013) Gender and corporate finance: Are male executives overconfident relative to female executives? Journal of Financial Economics 108 (3): 822-839. https://doi.org/10.1016/j.jifneco.2012.12.005

Jogulu UD, Wood UD (2006) The role of leadership theory in raising the profile of women in management. Equal Opportunities International 25 (4): 236-250. https://doi.org/10.1108/02610150610706230

Kittilaksanawong W, Zhao H (2018) Does lending to women lower sustainability of microfinance institutions? Moderating role of national cultures. Gender in Management: An International Journal 33 (3): 187-202.

https://doi.org/10.1108/GM-11-2015-0098.

Krishnan HA, Park D (2005) A few good women-on top management teams. Journal of Business Research 58 (12): 17121720. https://doi.org/10.1016/j.jbusres.2004.09.003

Leite RdO, Mendes LDS, Sacramento LC (2018) To profit or not to profit? Assessing financial sustainability outcomes of microfinance institutions. International Journal of Finance Economics, 1-13. https://doi.org/10.1002/ijfe.1718

Maes JP, Reed LR (2012) State of the microcredit summit campaign report 2012. Microcredit Summit Campaign.

Mandell B, Pherwari S (2003) Relationship between emotional intelligence and transformational leadership style: A gender comparison. Journal of Business and Psychology 17 (3): 387404. https://doi.org/10.12691/education-2-12-22

Mengoli S, Odorichi V, Gudjonsson S (2017) The scorpion who stings the dog who bites: The effect on women's different job positions on gender discrimination in microfinance. Journal of Research in Gender Studies 7 (1): 137-165. https://doi.org/10.22381/JRGS7120175

Mersland R, Strom RO (2009) Performance and governance in microfinance institutions. Journal of Banking and Finance 33 (4): 662-669. https://doi.org/10.1016/j.jbankfin.2008.11.009 Miller T, Triana MdC (2009) Demographic diversity in the boardroom: mediators of the board diversity - firm performance relationship. Journal of Management Studies 46 (5): 755-786. https://doi.org/10.1111/j.1467-6486.2009.00839.x

Moreno-Gómez J, Lafuente E, Vaillant Y (2018) Gender diversity in the board, women's leadership and business performance. Gender in Management: An International Journal 33 (2): 104-122. https://doi.org/10.1108/GM-05-2017-0058

Niederle M, Vesterlund L (2007) Do women shy away from competition? Do men compete too much? Quarterly Journal of Economics 122 (3): 1067-1101.

https://doi.org/10.1162/qjec.122.3.1067

Opstrup N, Villadsen AR (2015) The right mix? Gender diversity in top management teams and financial performance. Public Administration Review 75 (2): 291-301.

https://doi.org/10.1111/puar.12310

Powell M, Ansic D (1997) Gender differences in risk behaviour in financial decision-making: An experimental analysis. Journal of Economic Psychology 18 (6): 605-628. https://doi.org/10.1016/S0167-4870(97)00026-3

Reed LR (2011) State of the microfinance summit campaign report 2011. Microfinance Summit Campaign.

Rosenstein S, Wyatt JG (1990) Outside directors, board independence, and shareholder wealth. Journal of Financial Economics 26 (2): 175-191.

https://doi.org/10.1016/0304-405X(90)90002-H

Serrano-Cinca C, Gutiérrez-Nieto B (2014) Microfinance, the long tail and mission drift. International Business Review 23 (1): 181-194.

https://doi.org/10.1016/j.ibusrev.2013.03.006

Shrader CB, Blackburn BV, Iles P (1997) Women in management and firm financial performance: An exploratory study. Journal of Managerial Issues 9 (3): 355-372.

Singh V, Vinnicombe S, Johnson P (2001) Women directors on top UK boards. Corporate Governance: An International Review 9 (3): 206-216. https://doi.org/10.1111/1467-8683.00248

Smith N, Smith V, Verner M (2006) Do women in top management affect firm performance? A panel study of 2,500 Danish 
firms. International Journal of Productivity and Performance Management 55 (7): 569-593.

https://doi.org/10.1108/17410400610702160

Strom RO, D’Espallier B, Merlsand R (2014) Female leadership, performance, and governance in microfinance institutions. Journal of Banking and Finance 42: 60-75. https://doi.org/10.1016/j.jbankfin.2014.01.014

Sunden AE, Surette BJ (1998) Gender differences in the allocation of assets in retirement savings plans. American Economic Review 88 (2): 207-211 https://EconPapers.repec.org/ RePEc:aea:aecrev:v:88:y:1998:i:2:p:207-11
Tchakoute-Tchuigoua H, Soumaré I (2019) The effect of loan approval decentralization on microfinance institutions' outreach and loan portfolio quality. Journal of Business Research 94: 1-17. https://doi.org/10.1016/j.jbusres.2018.09.021

Vishwakarma R (2017) Women on board and its impact on performance: evidence from microfinance sector. Indian Journal of Corporate Governance 10 (1): 58-73.

https://doi.org/10.1177/0974686217701465 